УДК 37.013

DOI:

Тетяна Довгодько, кандидат педагогічних наук, доиент, дочент кафедри філологічних і природничих дисииплін Національного авіаційного університету Олена Корчук, кандидат технічних наук, старший науковий співробітник, завідувач кафедри філологічних і природничих наук Національного авіаційного університету

\title{
ДІДЖИТАЛІЗАЦІЯ ЯК СОЦІОКУЛЬТУРНИЙ ФЕНОМЕН: ФІЛОСОФСЬКО-ОСВІТНІЙ АСПЕКТ
}

Розглядається діджиталізачія як сочіокультурний феномен, що став складовою розвитку всіх сфер життєдіяльності сучасного сочіуму (освіти зокрема). Зазначається, шо діджиталізація є одним 3 найскладніших, комплексних й малодосліджених сочіально-економічних явищ. Вона постає перспективним напрямом розвитку сучасного закладу вищої освіти. Оцінено стан використання иифррових технологій висвітлено перспективні напрямки діджиталізації в освіті. Розкрито значення (поряд з інтернетизацією, інформатизачією, цифровізацією) застосування смарт-освіти угалузі вищої освіти. 3 'ясовано основні вимоги до спеиіаліста майбутнього. Визначено ступінь інституційного забезпечення стимулювання розвитку иифрових технологій у сфері університетської освіти. Підкреслюється, щзо сучасні ичифрові технології не замінюють, а лише доповнюють класичну освіту.

Ключові слова: діджиталізація; ичифрові технології; смарт-освіта; університетська освіта; інформатизачія; освітнє середовище.

Jim. 17.

Tetyana Dovhodko, Ph.D.(Pedagogy), Associate Professor of the Philology and Natural Sciences Department National Aviation University

Olena Korchuk, Ph.D.(Engineering), Senior Researcher, Head of the Philology and Natural Department National Aviation University

\section{DIGITALIZATIONAS A SOCIO-CULTURAL PHENOMENON: PHILOSOPHICALAND EDUCATIONALASPECTS}

Digitalization is considered as a socio-cultural phenomenon that has become a component of the development of all spheres of life of modern society (in particular education). It is indicated that digitalization is one of the most difficult, complex and little-studied socio-economic fact. It is appearing as a perspective direction in the development of modern higher educational institutions. It has assessed condition of the use of digital technology. The article analyzed the documents adopted in Ukraine about informatization of education, implementation of e-learning and distance learning. The perspective areas of digitalization are reflected and add as well as main challenges of realization of the state policy in this sphere. The meaning of the use of smart-education in the field of higher education (together with internetization, informatization, and digitalization) is revealed. The characteristics of the smart-education are not limited only to information and digital technologies, but also to increase intellectual educational environments. These technologies allow not simply and operatively find actual scientific achievements, but also those, that are able to solve certain production problems in the future. The learning and teaching process built on the basis of smart technologies becomes flexible, creative character traits, which includes both exploratory and cognitive, and project activities as such.

The basic requirements to the specialist of the future are found out. It is determined the degree of institutional providing for development stimulating of digital technologies in the field of university education. However it should be noted that the modern digital technologies do not replace, but only complement classical education, allow expanding the use of distance learning model and develop the academic mobility. It is actively searching for efficient implementation, which will compromise with traditions and innovations, classical and digitalized approaches are promoted to increase the students' interest in the learning process and improve the general level and quality of forthcoming education.

Keywords: digitalization; digital technologies; smart education; university education; informatization; an educational environment. 
сучасного соціуму, створюючи нові можливості для подальшого розвитку та функціонування. Важливою складовою існування й розвитку суспільства виступає система освіти, що також зазнала потужного інформаційного впливу. Розвиток інформаційно-комунікаційних технологій (IКT) актуалізує розробку нових інструментів навчання і сприяє формуванню принципово нових його засад, заснованих на “гейміфікації" та “діджиталізації” освіти, де на зміну традиційним викладачам-педагогам приходять “ігропедагоги”, “координатори онлайн-платформ і освітніх інноваційних траєкторій”.

Для сучасних розвинених країн притаманні різні тенденції впровадження й застосування IКТ в освіті. Дехто широко використовує ноутбуки, планшетні комп'ютери та мобільні пристрої, що впливає на нові форми навчання. Водночас деінде (особливо у сільській місцевості) спостерігається обмежений доступ до комп'ютерів, що породжує “цифрову нерівність".

Аналіз основних досліджень і публікацій. У зарубіжних дослідженнях з'являється все більше публікацій щодо впровадження IКТ у галузь освіти та перешкод, які при цьому зустрічаються. Зокрема, в праці Дж. Андерсона (Anderson, Jonathan. ICT transforming Education. A regional guide. Bangkok: UNESCO, 2010) зазначається, що IКТ, будучи надзвичайно ємним терміном, включає як методи, так і засоби: ноутбуки, планшети, смартфони, Інтернет, Wi-Fi, принтери, сканери, інтерактивні дошки тощо. Він уважає, що впровадженню інноваційних способів сприяють програмне забезпечення Skype, найбільша у світі соціальна мережа Фейсбук (Facebook), найпопулярніший серед користувачів пошуковий сервіс Google, у власності якого $є$ зокрема YouTube i Blogger. Зазначені інформаційно-комунікаційні засоби надають можливість у процесі навчання вийти за рамки аудиторії, стати мобільними, доступними й усюдисущими.

Основні тенденції ІКТ в освіті досліджували іспанські педагоги М. Кармона та з Х. Марін (ICT TRENDS IN EDUCATION 1st Annual International Interdisciplinary Conference, AIIC 2013, 24-26 April, Azores, Portugal, p. 428-430). Цією ж проблемою опікувались австралійські дослідники (Tondeur, J., Forkosh-Baruch,A., Prestridge, S., Albion, P. Educational Technology \& Society, 19 (3), 2016, p. 110-120. "Responding to Challenges in Teacher Professional Development for ICT Integration in Education") та вчені інших країн.

Вітчизняні науковці також мають чимало публікацій з розглядуваної проблеми. Так, у колективній монографії за редакцією В. Бикова йдеться про теоретичні й практичні питання формування єдиного освітнього простору [6]. Колективом авторів розглянуто проблеми створення засобів ІКТ з метою їх впровадження у систему освіти. $С$ також статті, присвячені питанням інформатизації в Україні [12] та розвитку й впровадженню інформаційних технологій в освіту $[4,5]$. У публікації Т. Вдовичин та А. Яцишин описано зміст понять “е-навчання", “інформаційно-освітнє середовище” та розглянуто можливості інформатизації навчального процесу [1].

Метою дослідження $є$ вивчення досвіду застосування ІКТ і діджиталізації загалом в освітньому процесі задля з'ясування шляхів їх раціонального впровадження в освіту.

Виклад основного матеріалу. Тлумачення феномена інформатизації освіти передбачає розроблення, упровадження технології використання ІКТ для формалізації і розв'язання задач у будь-яких галузях освіти. Як зазначається у Женевській декларації принципів [15] необхідним $\epsilon$ полегшення доступу до інформаційнокомунікаційної інфраструктури та технологій, до інформації і знань; підвищення рівня компетентності; підвищення рівня довіри й безпеки при застосуванні IКТ; створення сприятливого середовища на всіх рівнях; розширення й розвиток IКТ-додатків тощо.

Величезний вплив на процеси інформатизації освіти в зарубіжних країнах здійснили Світовий саміт з питань інформаційного суспільства у Женеві (2003) та Світовий саміт ООН з питань інформатизації у Тунісі (2007), а також документи, прийняті ЮНЕСКО. КЛючовим пріоритетом цього спеціалізованого органу ООН з питань освіти, науки та культури визначено надання допомоги у розробці стратегії і реалізації політики інформатизації освіти. Зокрема, виділено такі принципи: глобальні проблеми освіти, а саме, завдання “Освіти для всіх"; збалансоване застосовування класичних і нових технологій. При цьому радіо- і телепередачі, як і відео-технології, і надалі вважаються дієвими і ефективними засобами навчання поряд з Internet-навчанням та дистанційною освітою; без дистанційного або віртуального навчання потреба у вищій освіті не може бути ефективною у будь-яких країнах сучасного світу.

Україна визначила своїм орієнтиром входження в освітній і науковий простір Європи, то ж можна вважати, що реформування системи освіти України пов'язане із загальною тенденцією розвитку систем освіти європейських країн. В 
Україні реалізуються принципи Женевської декларації, Женевський план дій, Туніські зобов'язання та Туніська програма для інформаційного суспільства. Прийнято низку документів з інформатизації освіти, впровадження електронного i дистанційного навчання, здійснюється підвищення кваліфікації вчителів і викладачів у галузі ІКТ, реалізується процес відкритого доступу до інформації [11].

Новим етапом у розвитку інформатизації освіти стає діджиталізація, яка поступово, але кардинально змінює традиційну освіту. Учні та студенти вже поіншому сприймають інформацію, адже у цифровому світі запам'ятовування фактів, формул і вивчення дат відходить на другий план. Актуальним постає вміння правильно й уміло поводитися з інформацією, швидко іiї знаходити, обробляти і аналізувати.

Діджиталізація у сучасному житті є одним 3 найскладніших, комплексних й малодосліджених соціально-економічних і соціокультурних явищ. Термін “діджиталізація” походить від англійського "didgitalization" (digital - цифра) і перекладається як “оцифровування”, тобто представлення різноманітної інформації (текстів, звуків, відео тощо) у цифровому вигляді. При цьому зазначимо, що явище діджиталізації передусім стосується людей, які залучені до взаємодії з цифровими технологіями. 3 появою діджиталізації навчання стає більш ефективним і доступним. Відсутність умовних географічних бар'єрів для поширення цифрових технологій, глобальна доступність інформації і необмеженість її обсягу показують, що діджиталізація стає невід'ємною частиною галузі освіти.

Як зазначають дослідники цього феномена, діджиталізація в Європейському Союзі розвивається за такими напрямами: цифрове суспільство; дослідження та інновації; доступ до комунікації (телекомунікації; відкритий Інтернет тощо); цифрова освіта $[13 ; 14]$.

В Україні поступ діджиталізації успішно відбувається у напрямах електронного навчання (e-learning), IT (інформаційних технологій), ТКП (телекомунікаційних послуг) тощо. Поширенню діджиталізації в освіті сприяє також запровадження 4-G зв'язку.

Для України основною проблемою реалізації державної політики у сфері діджиталізації $є$ фрагментарність, відсутність системності, узгодженості між ухваленням нормативноправових актів і подальшою розробкою механізмів їх реалізації. 3 огляду на це уряд України затвердив Концепцію розвитку цифрової економіки і суспільства України на 2018-2022 роки, розробив план дій і визначив терміни виконання. У цій Концепції конкретизується питання розвитку інформаційного суспільства, інформатизації основних сфер життєдіяльності суспільства і загалом філософія діджиталізації. В основі Концепції - ініціатива і проєкти, які в сучасних розвинених країнах у тих чи тих сферах уже реалізовані. Вона грунтується не на футурологічних засадах, а на інформаційних технологіях, які використовуються у різних країнах світу, роблять їх більш успішними i конкурентоздатними.

В аналітичних матеріалах Міжнародного Давоського економічного форуму (2020) визначено перелік цифрових технологій, до яких віднесемо хмарні і мобільні технології, блокчейн, технології віртуалізації, ідентифікації, штучного інтелекту, біометричні технології, адитивні (3Dдрук) і т.д.

Цифровізація сьогодні є частиною політики держави. Це - зокрема цифрові інфраструктури, в тому числі широкополосний і мобільний Інтернет.

“Цифрові технології, - як заявила Генеральний директор ЮНЕСКО Ірина Бокова в своєму посланні з нагоди Міжнародного дня грамотності, - проникають в усі сфери нашого життя, докорінно змінюючи нашу роботу, навчання, спілкування" [9].

“Цифрова" грамотність (або "цифрова" компетентність) визнана ЄС однією з восьми ключових компетенцій для повноцінного життя та діяльності. У 2016 р. ЄС представив оновлений фреймворк Digital Competence, що складається 3 основних п'яти блоків компетенцій, а саме: інформаційна грамотність та грамотність щодо роботи 3 даними; комунікація і взаємодія; цифровий контент; безпека; розв'язання проблем. Означені блоки слугують підгрунтям для досягнення успіху людини у будь-якій сфері, у тому числі в освіті.

Завдячуючи цифровим технологіям (ЦТ), викладачі звільнятимуться від рутинної роботи, зокрема, від великої кількості паперових документів. Сучасні ЦТ надають можливість працювати над будь-яким проєктом у студентській групі, обмінюватися думками й ідеями з однокурсниками та викладачами, досягати кращих результатів протягом меншого часу. Такі засоби ЦТ, як інтерактивні планшети у ході проведення семінарів та конференцій дають змогу зацікавити набагато більшу кількість учасників, а 3D технологія моделювання візуалізувати й полегшити розв'язання складних проблем творчим і неформальним способом.

Дослідники прогнозують, що вже незабаром 
зникне потреба записувати лекції рукою, оскільки кожний студент зможе їх отримувати у цифровому форматі, осмислювати у режимі реального часу й проводити інтерактивну роботу з примітками, що практично виключить негативні наслідки від пропусків занять. Інтенсивна інтеграція ЦТ в освіту породила нову галузь сучасної науки цифрову гуманітаристику (Digital humanities), що останнім часом посіла чільне місце в гуманітарних міждисциплінарних комп'ютеризованих дослідженнях. “Цифровий перехід” у гуманітарних науках вже відбувся, оскільки фактично будь-яке гуманітарне дослідження сьогодні грунтується на спонтанній чи систематичній, вибірковій або суцільній оцифровці документів і об'єктів історикокультурної спадщини. Оцифровування стало одним 3 важливих практик ремесла вченогогуманітарія [2].

Цікавими є дослідження вчених Даремського університету щодо впливу ЦТ на освіту. Вони прийшли до висновків, що діджитал-технологія повинна лише доповнити, а не витісняти традиційні освітні методики. Вона найбільш повно реалізується у роботі з учнями, які уповільнено засвоюють матеріал або мають особливі потреби. Окрім того, найкращі результати, за словами означених вчених, можуть бути досягнуті, якщо використання інформаційних технологій $є$ періодичним. А от постійне й безперервне застосування інноваційних методів може поступово зменшити їх ефективність у засвоєнні інформації [17, 72-80]. Цю точку зору щодо дієвості й ефективності діджиталізації освіти розділяють також українські дослідники [7; 10; 11], які зазначають, що студенти можуть навчатися самостійно, використовуючи ЦТ, однак це не означає, що вони зможуть вчитися без педагогічного супроводження. Студенти потребують викладача-наставника, який спрямовуватиме навчання. Вміння читати і писати не свідчить про те, що індивід може здобути вищу освіту, лише читаючи книги в бібліотеці. Хоча, безсумнівно, цифрові бібліотеки та цифрові ресурси значно розширюють навчальні можливості студента.

Цифровізація вже зараз змінює традиційну систему освіти у напрямкі формування іiі нової якості: налагоджуються горизонтальні i вертикальні зв'язки між факультетами, університетами, підприсмствами, інвесторами; створюються національна освітня платформа, нові методи мотивації до участі і формування навичок цифрової та інноваційної діяльності; зростає інтерес до інноваційної культури університету, його проєктів. Сьогодні у вищій освіті простежуються ключові зміни: окрім забезпечення навчального процесу, університети стають майданчиком для створення інновацій, що неможливо без злиття з наукою і практикою; відбувається об'єднання ресурсів для реалізації спільних проєктів, створення науково-освітніх on-line платформ; з'явилась можливість вибудовування персоніфікованих освітніх траєкторій; поряд з традиційною освітою суспільство почало користуватися нетрадиційною, що можна пояснити зростанням компетенцій до інновацій [10].

Завдяки розвитку ІКТ все більшого поширення набуває дистанційна форма навчання. Цифровізація навчання дає змогу збільшити віртуальну мобільність студентів, навчатися й стажуватися в університетах інших країн. Цифровізація освітніх послуг уможливлює конкуренцію України в межах єдиного європейського освітнього простору й розвиток академічної мобільності.

Багатообіцяючим напрямом інтеграції закладів освіти у міжнародний освітній простір, є залучення іноземних студентів, відкриття міжнародних кампусів тощо. Українські університети вже працюють над цим. Так, за даними МОН України кількість іноземних студентів, які навчаються в 455 українських закладах вищої освіти (2019-2020рр.), досягла 80470 осіб. Порівнюючи дані з 2011 роком (53664 осіб), можна стверджувати, що з кожним роком все більше іноземних громадян прагнуть здобути вищу освіту в українських університетах. Причинами збільшення кількості іноземних студентів $є$ не лише фінансова доступність навчання у порівнянні з європейськими країнами, а й активне впровадження IT, діджиталізація, що дозволяє за рівнем освіти йти на рівні із розвиненими країнами.

Особливого значення набуває аналіз розвитку діджиталізації у закладах вищої професійної освіти. Так, за твердженням відомого французького філософа, дослідника цифрових технологій П'єра Леві, 3 60-х років XX ст. стає неможливим підтримувати професійну й наукову ідентичність усталеною протягом всього життя [16]. Знання, що $є$ необхідними для професійної та наукової діяльності, постійно розвиваються відповідно до зовнішніх умов і сприяють новому навчанню, зміні та реорганізації структури своїх знань [3].

Практика впровадження ЦТ в професійну освіту свідчить про те, що остання буде зміщуватися всередину компаній і корпорацій, ближче до менторів і робочих місць, до прикладних кейсів і буде неперервною: допоки працюєш - вчишся. I навпаки: допоки вчишся працюєш. 


\section{ДІДЖИТАЛІЗАЦІЯ ЯКСОЦІОКУЛЬТУРНИЙ ФЕНОМЕН: ФІЛОСОФСЬКО-ОСВІТНІЙ АСПЕКТ}

Враховуючи вищезазначене, можна виділити основні вимоги до спеціаліста майбутнього. Він повинен: 1) бути крос-функціональним працювати на стику професій; 2) уміти працювати віддалено; 3 ) бути професіоналом big date - уміти збирати й осмислювати великий об'єм інформації; 4) уміти самонавчатися (розвиток IT-технологій буде стрімким); 5) бути “універсальним солдатом": знати декілька мов, володіти soft skills --умінням терпляче, доброзичливо і спокійно досягати мети; 6) бути топовим і перенавчатися все життя; 7) бути готовим змінювати до 10 професій протягом життя; 8) бути здатним до науки (більшість видів робіт будуватиметься на комп'ютерних технологіях); 9) бути готовим до крос-культурних переміщень, працювати у різних країнах у зв'язку з глобалізацією.

Дослідники прогнозують, що через 10 років багато робітничих спеціальностей зникнуть, оскільки їх роботизують, водночас зросте попит на такі спеціальності: 1) web-розробники, програмісти й аналітики у сфері обчислювальної техніки та інформаційної безпеки, інженери 3 машинного навчання (ці працівники можуть максимально повно реалізовувати потенціал технологій на базі штучного інтелекту); 2) віртуальні адвокати (у США вже зараз набирає обертів юридичний супровід клієнтів у режимі онлайн); 3) бренд-менеджери, PR-менеджери. А оскільки зростатиме кількість фрілансерів, знадобляться послуги тайм-менеджерів, які будуть організовувати та продавати робочий час інших людей; 4) ГМО-агрономи і спеціалісти, які створюватимуть штучні органи на 3D-принтерах для заміни пошкоджених; 5) розробники “розумних будинків”, де людина майже не займатиметься домашніми справами; 6) педагоги, які вмітимуть індивідуалізувати навчання та створюватимуть індивідуальні навчальні програми; 7) аналітики Big Data.

На наш погляд, своєрідним різновидом (або складовою), поряд з цифровізацією, гейміфікацією, IКТ, інтернетизацією, інформатизацією дистанційною освітою, є смарт-освіта. Цей досить новий термін в освітньому середовищі вже років десять обговорюється, однак не може віднайти своє місце в педагогічних дослідженнях і освітній діяльності. Характеристики смартосвіти зводяться не лише до інформаційних та цифрових технологій, але й підвищення інтелектуальних освітніх середовищ.

Ефективність застосування “смарт-технологій” найбільш яскраво зможе проявлятися у сфері вищої освіти. Означені технології дають можливість не просто оперативно віднаходити необхідні на даний момент актуальні наукові доробки, але й такі, що здатні у майбутньому розв'язати певні виробничі проблеми. Загалом навчальний процес, побудований на основі смарттехнологій, набуває гнучкого, творчого характеру, що включає і пошуково-пізнавальну, і проєктну діяльність [5, 54-55].

Зміни в освіті можуть призвести до “занепаду” традиційних освітніх закладів (шкіл, університетів), а смарт-технології надають можливість різним категоріям користувачів в ініціативному й інтерактивному вигляді отримувати освіту. Але при цьому зарано говорити про розвал чи занепад традиційної освіти, оскільки вона поступово розвивається і вже деінде у навчальних планах й програмах 3'являються відкриті он-лайн курси й цифрові освітні ресурси. У матриці смартосвіти розвиваються нові освітні платформи, створюються системи діагностики, досліджуються нові формати подачі інформації й інструменти, що забезпечують інтерактивну взаємодію тих, хто навчається [8,15]. У перспективі смарт-освіта як поняття, що віддзеркалює тренди освіти, такі як цифровізація, розумні середовища, персоналізація навчання, мають всі шанси на закріплення у термінологічному словнику педагогіки.

Висновки і перспективи подальших розвідок. Вища освіта в європейських країнах (як і в Україні) перебуває, з одного боку, на межі перетворень, які інтегрують нові технології у навчальний процес, а $з$ іншого, вона намагається продукувати нові моделі впровадження IT в діяльність університетів, застосовуючи принцип поєднання традицій з інноваціями, використовуючи класичний і діджиталізований підходи аби підвищити зацікавленість студентів у процесі навчання й підвищити загальний рівень освіти.

Сьогодні можна з упевненістю говорити про те, що діджиталізація - це перспективний механізм оновлення й розвитку сучасного закладу вищої освіти.

Стосовно подальшого дослідження означеної проблематики слід підкреслити, що у найближчому майбутньому освіта в університетах має базуватися на різнобічно орієнтованих підходах, мати можливість гнучко розвиватись і включати в себе нові моделі.

\section{ЛІТЕРАТУРА}

1. Вдовичин Т.Я., Яцишин А.В. Застосування технологій відкритої освіти для інформатизації навчального процесу. Інформаційні технологї в освіті. Херсон, 2013. Вип.16. С.134-140.

2. Володин A.Ю. Digital humanities (цифровые 
гуманитарные науки): в поисках самоопределения. Вестник Пермского университета. Серия: История. Пермь, 2014. Вып.3.С. 5-9.

3. Гуменюк В., Хомяков В., Ажгалиева Б. Диджитализация как один из современных этапов развития общества на примере высшего образования. Успехи современной науки и образования. Серия "Педагогические науки". Белгород, 2019. №2. С.4-9.

4. Довгодько T.I. Викладання дисципліни "Математика" іноземним студентам із використанням новітніх ІКТ (на прикладі Національного авіаційного університету). Сучасні інформаційні технології та інноваційні методики навчання у підготовияі фахівців: методологія, теорія, досвід, проблеми. Вінниця, 2015. Вип. 43. С. 241-245.

5. Довгодько, Т.I., Драпогуз, В.П., Корчук, О.Ю. Smart-освіта як нова освітня парадигма. Неперервна педагогічна освіта ХХІ століття: зб. матеріалів XVII Міжн. педагогічно-мистецьких читань пам'яті проф. О.П. Рудницької. Київ, 2020. Вип. 3 (15), С. 53-55.

6. Лапінський В.В., Пилипчук А.Ю., Шишкіна М.П. та інш. Засоби інформаційно-комунікаційних технологій єдиного освітнього простору системи освіти України. Київ, 2010. 160 с.

7. Ляхоцька Л.Л. Роль цифрових технологій в освітньому процесі закладу післядипломної освіти. Science Review, 2018. №3(10), C. 64-67. URL: https://www.academia.edu/36464570/ (дата звернення: 10.09.20).

8. Новости ООН. 2017. URL: https://news.un.org/ ru/story/2017/09/1310481. (дата звернення: 05.08.20).

9. Осадча Л.А. Психологічні особливості впровадження та використання цифрових технологій в освітніх процесах у вузі. 2019. URL: https://www.inter-nauka.com/uploads/public/ 15514700263422.pdf (дата звернення: 01.10.20).

10. Осадчий В.В., Осадча К.П. Сучасні реалії і тенденції розвитку інформаційно-комунікаційних технологій в освіті. 2015. URL: file://C:/Users/ User/Downloads/ITZN_2015_48_4_6.pdf (дата звернення: 02.10.20).

11.Шишкіна М.П., Спірін О.М., Запорожченко Ю.Г. Проблеми інформатизації освіти України в контексті розвитку досліджень оцінювання якості засобів ІКТ. Інформаційні технологї $i$ засоби навчання. 2012. №1 (27). URL: https://core.ac.uk/ download/pdf/11084299.pdf (дата звернення: 12.11.20).

12. Declaration of Principles. Building the Information Society: a global challenge in the new Millennium.(2003). URL: https://www.itu.int/net/wsis/ docs/geneva/official/dop.html (дата звернення: 09.08.20).

13. Digital Agenda for Europe. 2020. URL: https:/ /www.europarl.europa.eu/factsheets/en/sheet/64/ digital-agenda-for-europe (дата звернення: 08.08.20).

14. The Global Information Technology Report. Growth and Jobs in a Hyperconnected World 2013. URL: http://www3.weforum.org/docs/WEF_GITR _Report_2013.pdf(дата звернення: 09.08.20).

15. Guide to measuring information and communication technologies (ICT) in education. (2009). United Nations Educational, Scientific and Cultural Organization; UNESCO Institute for statistics. Montreal : UNESCO-UIS. 138 p.

16. Levy, P. Collective intelligence. New York, 1997. Plenum, Harper Collins. pp. 253 - 258.

17. Pearce Nick, Weller Martin, Scanlon Eileen, Kinsley Sam Digital scholarship considered: how new technologies could transform academic work. Durham Research Online, 2011. 16 (1). pp. 72-80.

\section{REFERENCES}

1. Vdovychyn, T.Ia. (2013). Zastosuvannia tekhnolohii vidkrytoi osvity dlia informatyzatsii navchalnoho protsesu [Application of open education technologies for informatization of educational process]. Information technology in education. Kherson, Vol.16, pp.134-140. [in Ukrainian].

2. Volodin, A.Yu. (2014). Digital humanities (tsifrovye gumanitarnye nauki): v poiskakh samoopredeleniya [Digital humanities (digital humanities): in the search of self-determination]. Journal of the Permian University. Series: history. Permian, Vol.3, pp. 5-9. [in Russian].

3. Gumenyuk, V., Khomyakov, V. \& Azhgalieva, B. (2019). Didzhitalizatsiya kak odin iz sovremennykh etapov razvitiya obshchestva na primere vysshego obrazovaniya [Digitalization as one of the modern stages un the development of society on the example of higher education]. "The successes of modern science and education". Monthly scientificpedagogical journal. Series: pedagogikal sciences. Belgorod, Vol. 2, pp.4-9. [in Russian].

4. Dovghodjko, T.I. (2015). Vykladannja dyscypliny "Matematyka" inozemnym studentam iz vykorystannjam novitnikh IKT (na prykladi Nacionaljnogho aviacijnogho universytetu) [The teaching "Mathematics" to foreign students with the use of ICT innovations (on the example of National Aviation University)]. "The modern technologies and innovative teaching methods in training: methodology, theory, experience, problems". Vinnytsia, Vol. 43, pp.241-245. [in Ukrainian].

5. Dovghodjko, T.I., Drapoghuz, V.P. \& Korchuk, O.Ju. 
(2020). Smart-osvita jak nova osvitnja paradyghma [Smart-education as a new educational paradigm]. The thesis of the Conference "Continuing pedagogical education of the XXI century”. Kyiv, Vol.3(15), pp.53-55. [in Ukrainian].

6. Lapinskyi, V.V., Ptlypchuk, A.Iu. \& Shyshkina, M.P. et al. (2010). Zasoby informatsiino-komunikatsiinykh tekhnolohii yedynoho osvitnoho prostoru systemy osvity Ukrainy [The means of information and communication technologies of the single educational space of the education system of Ukraine]. Kyiv, $160 \mathrm{p}$. [in Ukrainian].

7. Liakhotska, L.L. Rol tsyfrovykh tekhnolohii v osvitnomu protsesi zakladu pisliadyplomnoi osvity [The role of digital technologies in the educational process of postgraduate education]. Available at: https://www.academia.edu/36464570/ (Accessed 20 Sep. 20). [in Ukrainian].

8. Novosty OON. Available at: https:// news.un.org/ru/story/2017/09/1310481. (Accessed 05 Aug. 2020) [in Russian].

9. Osadcha, L.A. (2019). Psykholohichni osoblyvosti vprovadzhennia ta vykorystannia tsyfrovykh tekhnolohii v osvitnikh protsesakh u vuzi [Psychological features of introduction and use of digital technologies in educational processes in high school]. Available at: https://www.inter-nauka.com/ uploads/public/15514700263422.pdf (Accessed 01 Okt. 20). [in Ukrainian].

10. Osadchyi, V.V. \& Osadcha, K.P. (2015). Suchasni realii i tendentsii rozvytku informatsiinokomunikatsiinykh tekhnolohii v osviti [Modern realities and trends in the development of information and communication technologies in education]. Available at: file:///C:/Users/User/Downloads/ITZN_2015 _48_4_6.pdf(Accessed 02.10.20). [in Ukrainian].
11. Shyshkina, M.P., Spirin, O.M. \& Zaporozhchenko, Yu.H. (2012). Problemy informatyzatsii osvity Ukrainy v konteksti rozvytku doslidzhen otsiniuvannia yakosti zasobiv IKT [Problems of informatization of education in Ukraine in the context of the development of research to assess the quality of ICT tools]. Available at: https://core.ac.uk/download/pdf/11084299.pdf (Accessed 12 Nov. 20). [in Ukrainian].

12. Declaration of Principles. Building the Information Society: a global challenge in the new Millennium. Available at: https://www.itu.int/net/wsis/ docs/geneva/official/dop.html (Accessed 09 Aug. 20). [in English].

13. Digital Agenda for Europe. Available at: https:/ /www.europarl.europa.eu/factsheets/en/sheet/64/ digital-agenda-for-europe (Accessed 08 Aug. 20). [in English].

14. The Global Information Technology Report. Growth and Jobs in a Hyperconnected World 2013. Available at: http://www3.weforum.org/docs/ WEF_GITR_Report_2013.pdf (Accessed 09 Aug. 20). [in English].

15. Guide to measuring information and communication technologies (ICT) in education. United Nations Educational, Scientific and Cultural Organization ; UNESCO Institute for statistics. Montreal : UNESCO-UIS, 2009. 138 p. [in English].

16. Levy, P. (1997). Collective intelligence. New York: Plenum, Harper Collins, pp. 253 - 258. [in English].

17. Pearce Nick and Weller Martin and Scanlon Eileen and Kinsley Sam (2011). Digital scholarship considered: how new technologies could transform academic work. Durham Research Online, 16 (1), pp. 72-80. [in English].

Стаття надійшла до редакції 28.10.2020

\section{}

“Розум полягає не лише у знанні, але й у вмінні застосовувати иі знання”.

Apicmomeль

давньогрецький науковець-енииклопедист, білособ $і$ логік

"Якщо хочеш, щоб у тебе було досить вільного часу, щодня читай... Не шкодуй часу на те, иоб глибоко осмислити сутність бактів, явищ, закономірностей, з якими маєш cnpasy".

Василь Сухомлинсъқий уқраӥнський педагог, публіиист, письменник, поет

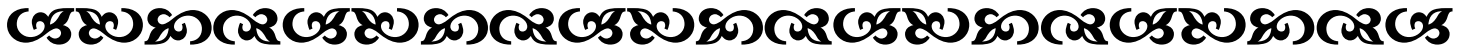

